\title{
ANALISIS KEMAMPUAN MATEMATIKA MAHASISWA PROGRAM STUDI PENDIDIKAN MATEMATIKA DALAM MENYELESAIKAN SOAL MODEL PISA LEVEL 4 KONTEN BILANGAN
}

\author{
Imelda Jebrina Bana ${ }^{1 *}$, Hermina Disnawati ${ }^{2}$, Selestina Nahak $^{3}$ \\ ${ }^{1}$ Mahasiswa Pendidikan Matematika Universitas Timor, ${ }^{2,3}$ Universitas Timor \\ *bana27imelda@gmail.com
}

Diterima: 30 Mei 2021. Disetujui: 08 Juni 2021. Dipublikasikan: 31 Juli 2021

\begin{abstract}
ABSTRAK
Indonesia menjadi salah satu negara yang mengikuti PISA sejak tahun 2000 hingga 2018, namun pencapaian prestasi siswa Indonesia pada tahun 2018 belum memuaskan. Hal ini diduga kuat salah satu faktor penyebabnya adalah guru, dimana masih banyak guru yang belum tahu tentang sistem penilaian PISA, soal-soal model PISA, dan cara menyelesaikan soal model PISA. Tujuan penelitian ini adalah menganalisis dan mendeskripsikan kemampuan matematika mahasiswa yang berkemampuan rendah, sedang dan tinggi dalam menyelesaikan soal model PISA level 4 konten bilangan. Metode penelitian ini adalah pendekatan kualitatif, penelitian ini telah dilaksanakan di Prodi Pendidikan Matematika Unimor, tahun 2020. Hasil penelitian ini menunjukan bahwa mahasiswa yang berkemampuan matematika rendah belum mampu menyelesaikan soal model PISA level 4 konten bilangan, sedangkan mahasiswa yang berkemampuan matematika sedang dan tinggi sudah mampu menyelesaikan soal model PISA level 4 konten bilangan.
\end{abstract}

Kata Kunci: Kemampuan Matematika; Soal Model PISA Level 4; Konten Bilangan

\begin{abstract}
Indonesia is one of the countries involved in PISA from 200 to 2018, but the achievements of Indonesia student in 2018 have not been satisfactory. It is strongly suspected that one of the strong causes is the teacher, where there are still many teachers who do not know about the PISA assessment system, the PISA model questions and how to solve the PISA model. The research objective of this study was to analyze and describe the mathematical abilities of students with low, medium and high abilities in solving problems in the PISA model level 4 number content. The research method of this research is a qualitative approach, this research was conducted in the Unimor Mathematics Educationg Study Program, 2020. The results of this study indicate that students who take good low math abilities have not been able to solve problems in the PISA model level 4 quantity content, while students with moderate and high mathematical abilities are already able to solve problems in the PISA model level 4 quantity content.
\end{abstract}

Keywords: Math Ability; PISA Model Level 4 Questions; Quantity Content

\section{Pendahuluan}

PISA (Programme for International Student Assessment) merupakan salah satu penilaian tingkat internasional yang diselenggarakan tiga-tahunan, oleh OECD (Organization For Economic Co-Operation And Development) yang melibatkan siswa berumur 15 tahun atau setara dengan siswa SMP yang pertama diseleggarakan pada tahun 2000 untuk bidang membaca, matematika dan sains. Indonesia merupakan satu dari negara yang terlibat dalam PISA sejak tahun 2000. Manfaat yang diperoleh siswa dalam 
mengikuti PISA adalah dapat mengaplikasikan konsep dari materi yang telah diterima di sekolah ke dalam masalah kehidupan sehari-hari melalui soal-soal yang dirilis PISA. Hasil studi PISA merupakan salah satu ukuran untuk melihat kemampuan pemecahan masalah matematika

Tabel 1. Peringkat Literasi Matematika Siswa Indonesia Pada PISA 2000-2019

\begin{tabular}{ccccc}
\hline Tahun & \multicolumn{2}{c}{ Skor Rata-Rata } & $\begin{array}{c}\text { Peringkat } \\
\text { Indonesia }\end{array}$ & $\begin{array}{c}\text { Jumlah Negara } \\
\text { Peserta PISA }\end{array}$ \\
2000 & 367 & 500 & 39 & 41 \\
2003 & 360 & 500 & 38 & 40 \\
2006 & 391 & 500 & 50 & 57 \\
2009 & 371 & 500 & 61 & 65 \\
2012 & 375 & 500 & 64 & 65 \\
2015 & 386 & 500 & 65 & 72 \\
2018 & 379 & 500 & 74 & 79 \\
\hline
\end{tabular}

Pengalaman Indonesia selama 20 tahun mengikuti PISA ternyata hasil PISA terbaru tahun 2018 prestasi siswa malah menurun dibanding PISA 2015. Hal ini diduga kuat salah satu faktornya adalah guru. Dimana masih banyak guru yang belum tahu tentang sistem penilaian PISA, soal-soal PISA, dan cara menyelesaikan soal PISA (Tohir, M 2019: 1). Menurut Sulastri, dkk (2014: 14) menyimpulkan bahwa FKIP/FIP sebagai salah satu lembaga yang menghasilkan calon guru turut bertanggungjawab membekali mahasiswa calon guru dengan soal-soal bertaraf internasional seperti soal PISA. Walaupun demikian, pada penelitian ini peneliti memilih soal model PISA level sedang yaitu level 4 untuk mengetahui kemampuan matematika pada mahasiswa Universitas Timor tepatnya pada program studi pendidikan matematika.

Semakin tinggi level kognitif soal, semakin sedikit mahasiswa calon guru yang dapat menyelesaikan soal PISA. Umumnya mahasiswa hanya mampu menyelesaikan soal level rendah yaitu level 1 dan 2, sehingga soal PISA level 4 masih dianggap sulit bagi mahasiswa karena membutuhkan penalaran yang sangat tinggi (Disnawati, H 2018: 778). Menurut Disnawati, H (2018: 777) dalam implementasinya bahwa lemahnya literasi matematika mahasiswa pada konten Quantity menimbulkan pertanyaan tentang kualitas pembelajaran yang dialami oleh mahasiswa di kelas termasuk muatan kurikulum yang berlaku. Oleh karena itu, konten bilangan perlu dianalisis dan dikenalkan kepada mahasiswa calon guru dari sekarang untuk membantu mahasiswa dalam menghadapi permasalahan di kehidupan nyata. Walaupun demikian, pada penelitian ini peneliti memilih soal model PISA level sedang yaitu level 4 konten bilangan untuk mengetahui kemampuan matematika pada mahasiswa Universitas Timor tepatnya pada program studi pendidikan matematika.

Pada penelitian ini, peneliti mengukur kemampuan matematika mahasiswa menggunakan tes sehingga mahasiswa dapat dikelompokkan berdasarkan tingkat kemampuan matematikanya yaitu kelompok kemampuan rendah, kelompok kemampuan sedang, dan kelompok kemampuan tinggi. Untuk kelompok kemampuan rendah dengan nilai kurang dari atau sama dengan 74 , kelompok kemampuan sedang dengan nilai di antara 75 dan 80. Sedangkan untuk kelompok kemampuan tinggi dengan nilai lebih dari atau sama dengan 80.

Soal kemampuan matematika pada PISA disusun untuk mengukur kemampuan logika dan penalaran siswa. saol tersebut memuat berbagai materi dan membutuhkan penalaran yang lebih mendalam untuk menyelesaikannya. Soal kemampuan matematika PISA menguji tiga aspek yakni konten (content), situasi dan konteks (situations and contexts), dan kompetensi atau proses (competencies/processes). 
Menurut $O E C D$ (2013), dikategori konten matematika dalam PISA dibagi menjadi empat bagian sebagai berikut.

a) Perubahan dan Hubungan (Change and Relationship), berkaitan dengan pertumbuhan organisme, musik dan siklus musim, pola cuaca, tingkat pekerjaan dan kondisi ekonomi. Konten ini berkaitan dengan fungsi aljabar, persamaan dan pertidaksamaan, tabel dan representasi grafis, yang menjadi pusat dalam menggambarkan, memodelkan, dan menafsirkan perubahan.

b) Ruang dan Bentuk (Space and Shape), mencakup berbagai bentuk meliputi bentuk visual, dan fisik: pola, sifat objek, posisi, dan orientasi, representasi dari objek, menguraikan dari informasi visual, navigasi dan interaksi yang dinamis dengan bentuk nyata. Geometri menjadi landasan penting dalam konten ruang dan bentuk ini.

c) Kuantitas (Quantity), berkaitan dengan hubungan bilangan dan pola bilangan. Konten bilangan melibatkan kemampuan untuk memahami ukuran, pola bilangan, dan segala sesuatu yang berhubungan dengan bilangan dalam kehidupan sehari-hari.

d) Ketidakpastian dan probabilitas (Uncertainty), dalam ilmu pengetahuan teknologi dalam kehidupan sehari-hari, selalu berkaitan dengan ketidakpastian karena ketidakpastian adalah hal penting dalam analisis matematis dari banyak situasi masalah. Teori peluang dan statistik serta teknik representasi data dan keterangan merupakan teori yang digunakan untuk menangani hal itu.

\section{Situasi dan Konteks (Situation and Context)}

Konteks ini dibagi menjadi empat situasi (Zulkardi, 2016) sebagai berikut:

a) Konteks pribadi (Personal), berhubungan dengan kegiatan pribadi siswa sehari-hari. Dalam menjalani kehidupan sehari-hari tentu para siswa menghadapi berbagai persoalan pribadi yang memerlukan pemecahan secepatnya. Matematika diharapkan dapat berperan dalam menginterpretasikan permasalahan dan kemudian memecahkannya.

b) Konteks pekerjaan (Profession), masalah yang diklasifikasikan dalam kategori konteks pekerjaan yang berpusat pada dunia kerja. Pengetahuan siswa tentang konsep matematika diharapkan dapat membantu untuk merumuskan, melakukan klasifikasi masalah, dan memecahkan masalah pendidikan dan pekerjaan pada umumnya.

c) Konteks umum (General), yang berkaitan dengan penggunaan pengetahuan matematika dalam kehidupan bermasyarakat dan lingkungan yang lebih luas dalam kehidupan sehari-hari. Siswa dapat menyumbangkan pemahaman mereka tentang pengetahuan dan konsep matematikanya itu untuk mengevaluasi berbagai keadaan yang relevan dalam kehidupan di masyarakat.

d) Konteks keilmuan, yang secara khusus berhubungan dengan kegiatan ilmiah yang lebih bersifat abstrak dan menuntut pemahaman dan penguasaan teori dalam melakukan pemecahan masalah matematika. Konteks ini dikenal sebagi konteks Intramathematical.

Kelompok Kompetensi (Competencies Group)

Kompetensi pada PISA dibagi dalam tiga kelompok (OECD, 2010) yaitu:

a) Kelompok Reproduksi (Reproduction Group), Pertanyaan pada PISA yang termasuk dalam kelompok reproduksi meminta siswa untuk menunjukan bahwa siswa mengenal fakta, objek-objek, dan sifat-sifatnya, ekuivalensi, menggunakan prosedur rutin, algoritma standar, dan menggunakan skill yang bersifat teknis.Item soal untuk kelompok ini berupa pilihan ganda, isian singkat, atau soal terbuka (yang terbatas).

b) Kelompok Koneksi (The Connection Group), Pertanyaan pada PISA termasuk dalam kelompok koneksi meminta siswa untuk menunjukan bahwa siswa dapat membuat hubungan antara beberapa gagasan dalam matematika dan beberapa informasi yang terintegrasi untuk menyelesaikan suatu permasalahan.Dalam koneksi ini siswa diminta untuk menyelesaikan masalah yang non-rutin tapi hanya membutuhkan sedikit translasi dari konteks ke model dunia matematika. 
c)

Kelom

pok Refleksi (The Reflection Group), Pertanyaan pada PISA yang termasuk dalam kelompok refleksi ini menyajikan masalah yang tidak terstruktur (instuctured situation) dan meminta siswa untuk mengenal dan menemukan ide matematika dibalik masalah tersebut. Kompetensi refleksi ini adalah kompetensi yang paling tinggi dalam PISA, yaitu kemampuan bernalar dengan menggunakan konsep matematika.Siswa dapat menggunakan pemikiran matematikanya secara mendalam dan menggunakannya untuk memecahkan masalah. Dalam melakukan refleksi ini, siswa melakukan analisis terhadap situasi yang dihadapinya, menginterpretasi, dan mengembangkan strategi penyelesaian mereka sendiri, Anisah (2013)

Level Kemampuan Matematika dalam PISA

PISA mengembangkan enam katogori kemampuan matematika siswa yang menujukkan kemampuan kognitif dari siswa.Tingkatan kemampuan matematika menurut PISA disajikan pada Tabel 2.berikut.

Tabel 2. Level Kemampuan Literasi Matematika Siswa Dalam PISA

\begin{tabular}{cl}
\hline Level & \multicolumn{1}{c}{ Aktivitas yang dilakukan siswa } \\
1 & $\begin{array}{l}\text { Siswa dapat menggunakan pengetahuaannya untuk menyelesaikan soal } \\
\text { rutin, dan dapat menyelesaikan masalah yang konteksnya umum. }\end{array}$ \\
2 & $\begin{array}{l}\text { Siswa dapat menginterprestasikan masalah dan menyelesaikan dengan } \\
\text { rumus. }\end{array}$ \\
3 & $\begin{array}{l}\text { Siswa dapat melaksanaan prosedur dengan baik dalam menyelesaikan } \\
\text { soal serta dapat memilih strategi pemecahan masalah. }\end{array}$ \\
4 & $\begin{array}{l}\text { Siswa dapat bekerja secara efektif dengan model dan dapat memilih } \\
\text { serta mengintergrasikan representasi yang berbeda, kemudian } \\
\text { menghubungkannya dengan dunia nyata. }\end{array}$
\end{tabular}

$5 \quad$ Siswa dapat kerja dengan model untuk situasi yang kompleks serta dapat menyelesaikan masalah yang rumit.

6 Siswa dapat menggunakan penalarannya dalam menyelesaikan masalah matematis, dapat membuat generalisasi, merumuskan serta mengkomunikasi hasil temuannya.

Sumber: Johar (Setiawan dkk, 2014: 247)

Berdasarkan Tabel 2. diperoleh bahwa penilaian literasi matematis yang dilakukan oleh studi PISA ini terdiri dari 6 tingkatan atau level. Soal literasi matematis level 1 dan 2 termasuk kelompok soal dengan skala bawah yang mengukur kompetensi reproduksi. Soal-soal disusun berdasarkan konteks yang cukup dikenal oleh siswa dengan operasi matematika yang sederhana. Soal literasi matematika level 3 dan 4 termasuk kelompok soal dengan skala menengah yang mengukur kompetensi koneksi. Soal-soal skala menengah memerlukan kompetensi siswa karena situasi yang diberikan tidak dikenal atau bahkan belum pernah dialami oleh siswa. Sedangkan, soal literasi matematika level 5 dan 6 termasuk kelompok soal dengan skala tinggi yang mengukur kompetensi refleksi. Soalsoal ini menuntut penafsiran tingkat tinggi dengan konteks yang sama sekali tidak terduga oleh siswa. Maryanti (Setiawan dkk, 2014: 147).

\section{Metode Penelitian}

Jenis penelitian ini adalah penelitian deskriptif kualitatif. Penelitian ini memiliki tahapan-tahapan sebagai berikut: 
a. Mereduksi data merupakan suatu bentuk analisis yang menajamkan, menggolongkan, mengarahkan, membuang data yang tidak perlu dan mengorganisasi data dengan sedemikan rupa sehingga kesimpulan akhir dapat ditarik dan diverifikasi

b. Penyajian data merupakan suatu kumpulan informasi tersusun, yang memberikan kemungkinan adanya penarkan kesimpulan dan pengambilan tindakan.

c. Kesimpulan, merupakan proses pengambilan intisari dan sajian data yang telah terorganisir dalam bentuk pernyataan kalimat atau formal yang singkat tetapi mengandung pergertian yang luas.

Penelitian ini telah dilaksanakan di Program Studi Pendidikan Matematika Universitas Timor tanggal $3-8$ september 2020 pada Tahun Akademik 2020/2021. Subjek penelitian mahasiswa yang sudah lulus mata kuliah Kapita Selekta Matematika yang berjumlah 16 orang, kenudian dipilih 6 orang untuk diwawancarai dimana dua orang yang mewakil mahasiswa berkemampuan rendah, dua orang yang berkemampuan sedang, dan dua orang yang berkemampuan tinggi. Instrument penelitian soal tes model PISA sebanyak 4 soal level 4 konten bilangan dan pedoman wawancara.

Teknik pengumpulan data yaitu 1) tes yang digunakan untuk memperoleh data mengenai kemampuan mahasiswa dalam menyelesaikan soal model PISA, 2) wawancara untuk mengetahui bagaimana mahasiswa mengerjakan soal dan menggali data terkait kemampuan mahasiswa dalam menyelesaikan soal. Teknik analisis data dalam penelitian ini meliputi: 1) Reduksi data, dalam hal ini peneliti mengumpulkan hasil tes serta mencatat hasil wawancara dan dokumentasi dari informan yang berkaitan dengan kemampuan mahasiswa dalam menyelesaikan soal. 2) Penyajian data, ini juga berbentuk teks naratif, teks dalam bentuk catatan hasil dengan informan penelitian sebagai informasi tersusun yang memberi kemungkinan adanya kesimpulan tentang faktor-faktor yang mempengaruhi kemampuan mahasiswa dalam menyelesaikan soal. 3) Penarikan kesimpulan untuk melihat kemampuan mahasiswa dapat diketahui berdasarkan hasil tes soal model PISA yang diberikan kepada mahasiswa dan hasil wawancara yang dilakukan peneliti kepada mahasiswa yang Berkemampuan Rendah, Sedang dan Tinggi.

\section{Hasil Penelitian dan Pembahasan}

Berdasarkan tes yang dilakukan diperoleh kemampuan mahasiswa dalam menyelesaikan soal matematika model PISA. Hasil tes dapat dilihat pada Tabel 3. berikut.

Tabel 3. Hasil Tes Soal Model PISA

\begin{tabular}{cccc}
\hline No & $\begin{array}{c}\text { Kategori Kemampuan } \\
\text { Mahasiswa }\end{array}$ & Nama & $\begin{array}{c}\text { Nilai Tes Soal } \\
\text { Model PISA }\end{array}$ \\
1 & Rendah & DL & 31 \\
2 & Rendah & MIK & 35 \\
3 & Rendah & MET & 25 \\
4 & Rendah & AS & 29 \\
5 & Rendah & CSD & 26 \\
6 & Sedang & OKK & 30 \\
7 & Sedang & ATT & 52 \\
8 & Sedang & FN & 30 \\
9 & Sedang & TM & 77 \\
10 & Sedang & PMA & 51 \\
11 & Sedang & DLT & 76 \\
12 & Sedang & DO & 76 \\
13 & Tinggi & ST & 87 \\
14 & Tinggi & DTK & 38 \\
15 & Tinggi & KHB & 88 \\
16 & Tinggi & HGTK & 92 \\
\hline
\end{tabular}


Selanjutnya akan disajikan hasil persentase mahasiswa menjawab benar berdasarkan level soal PISA, dan dapat dilihat pada Tabel 4. berikut.

Tabel 4. Hasil Pengerjaan Mahasiswa Dalam Menyelesaikan Soal Model PISA

\begin{tabular}{ccccccc}
\hline Konten & Konteks & $\begin{array}{c}\text { Level } \\
\text { Soal } \\
\text { PISA }\end{array}$ & $\begin{array}{c}\text { No } \\
\text { Tem } \\
\text { a }\end{array}$ & $\begin{array}{c}\text { Nomor } \\
\text { soal }\end{array}$ & $\begin{array}{c}\text { Banyak } \\
\text { Mahasiswa } \\
\text { Menjawab } \\
\text { Benar }\end{array}$ & $\begin{array}{c}\text { Persentase } \\
\text { Mahasiswa } \\
\text { Menjawab } \\
\text { Benar }\end{array}$ \\
\hline Bilangan & Umum & 4 & 1 & $1 \mathrm{a}, 1 \mathrm{~b}$ & 8 & $50 \%$ \\
Bilangan & Umum & 4 & 2 & $2 \mathrm{a}, 2 \mathrm{~b}$ & 1 & $6,25 \%$ \\
Bilangan & Pribadi & 4 & 3 & 3 & 3 & $18,75 \%$ \\
Bilangan & Umum & 4 & 4 & $4 \mathrm{a}, 4 \mathrm{~b}$ & 3 & $18,75 \%$ \\
\hline
\end{tabular}

Berdasarkan Tabel 4, terlihat bahwa persentase tertinggi mahasiswa menjawab dengan benar berada pada soal nomor 1, dimana soal tersebut merupakan soal yang sering dipelajari dan mudah untuk menentukan rumusnya. Sedangkan soal nomor 2 persentase mahasiswa menjawab benar adalah 6,25\%. Hal ini dikarenakan untuk soal tidak terbiasa dikerjakan atau belum tahu rumus untuk menyelesaikan soal.

\section{A. Mahasiswa Berkemampuan Matematika Rendah (DL dan MIK)}

Berdasarkan hasil analisis, mahasiswa DL dan MIK yang berkemampuan matematika rendah hanya mampu menjawab 1 tema dari 4 tema yang diberikan. Mahasiswa DL dan MIK hanya mampu menjawab dengan benar soal model PISA nomor 1a, 1b, 2b, dan 4a. Untuk soal 2a, 3, dan 4b, DL dan MIK tidak mampu menjawab. Mahasiswa DL mampu menjawab dengan benar soal model PISA nomor $2 \mathrm{~b}$ dan $4 \mathrm{a}$. ketika dikonfirmasi melalui wawancara, mahasiswa DL mampu menjawab benar dan menjelaskan secara detail langkah-langkah menyelesaikan soal tersebut. Untuk soal nomor 1 dan 3 mahasiswa mampu menjawabnya tetapi tidak benar. Ketika dikonfirmasi melalui wawancara, mahasiswa DL belum mampu dalam ketepatan perhitungan dalam soal tersebut. Selanjutnya Mahasiswa MIK mampu menjawab dengan benar soal model PISA nomor 1a dan 1b. Ketika dikonfirmasi melalui wawancara, mahasiswa MIK mampu menjelaskan langkah-langkah penyelesaiannya secara detail samapi menyimpulkan hasilnya dengan benar. Untuk soal nomor 2, 3 dan 4, mahasiswa MIK tidak mampu menjawab. Berdasarkan hasil wawancara, mahasiswa MIK mengatakan tidak paham terhadap soal tersebut.

Kemampuan kedua mahasiswa yang lain dalam PISA yaitu DL dan MIK adalah masih rendah. Hal ini sama dengan hasil penelitian Stacey (2011) tentang kemampuan siswa Indonesia yang rendah dalam PISA. Dengan kata lain, kemampuan guru sangat mempergaruhi kemampuan siswa, dimana kedua mahasiswa berada pada tingkat kemampuan cukup. Hal ini dikarenakan kedua mahasiswa ini tidak memahami permasalahan pada soal dengan baik sehingga penyelesaian yang dilakukan hanya tepat untuk sebagian kecil aspek analisis.

\section{B. Mahasiswa Berkemampuan Matematika Sedang (TM dan DO)}

Berdasarkan hasil analisis, mahasiswa TM yang berkemampuan matematika sedang, hanya mampu menyelesaikan 2 tema dengan benar dari 4 tema yang diberikan. Untuk soal model PISA nomor 1a, 1b, 2b dan 4a, 4b TM mampu menjawabnya dengan benar. Dan untuk soal nomor 2a dan 3, mahasiswa TM tidak mampu menjawab dengan benar. 
Ketika dikonfirmasi melalui wawancara, mahasiswa TM belum mampu mengidentifikasikan langkah-langkah dalam menyelesaikan permasalahan pada soal sehingga langkah-langkah penyelesaian sampai menyimpulkan hasil akhir tidak benar.

Sedangkan hasil analisis, mahasiswa DO yang berkemampuan matematika sedang hanya mampu menyelesaikan 2 tema dengan benar dari 4 tema yang diberikan. Mahasiswa DO mampu menjawab dengan benar soal nomor 1a, 1b, 2a, 2b dan 4a. Untuk soal nomor 3 dijawab salah dan $4 \mathrm{~b}$ tidak mampu menjawabnya. Ketika dikonfirmasi melalui wawancara, mahasiswa DO mengatakan tidak paham terhadap soal- soal tersebut.

\section{Mahasiswa Berkemampuan Matematika Tinggi (KHB dan HGTK)}

Dari hasil analisis, mahasiswa KHB yang berkemampuan matematika tinggi hanya mampu menyelesaikan 3 tema dari 4 tema yang diberikan. Mahasiswa mampu menjawab dengan benar soal nomor 1a, 1b, 2a, 3 dan 4a. untuk soal nomor $2 \mathrm{~b}$ mahasiswa KHB tidak mampu menjawab dengan benar. Ketika dikonfirmasi melalui wawancara, KHB sedikit keliru untuk menentukan hasil akhir dan untuk soal nomor 4b, mahasiswa KHB tidak mampu menjawab karena waktu tes sudah hampir selesai.

Selanjutnya Mahasiswa HGTK yang berkemampuan matematika tinggi mampu menjawab semua soal yang diberikan. Mahasiswa HGTK mampu menjawab soal nomor 1a, 1b, 3, dan 4a, 4b dengan benar. Untuk soal nomor 2 tidak mampu menjawab dengan benar. Berdasarkan wawancara, mahasiswa HGTK mampu mengidentifikasikan langkahlangkah dalam menyelesaikan permasalahan pada soal tetapi mengkalkulasinya kurang tepat sehingga kesimpulannya tidak benar.

Kemampuan kedua mahasiswa yang lain dalam PISA yaitu KHB dan HGTK adalah sangat baik. Hal ini sama dengan hasil penelitian Putri, Susanto dan Kurniati (2015) yang meyimpulkan bahwa siswa berkemampuan tinggi memiliki keterampilan yang optimal dalam mengontrol dan menyelesaikan setiap permasalahan.

\section{Kesimpulan}

\section{Simpulan}

Berdasarkan hasil dan pembahasan pada bab sebelumnya, maka dapat disimpulkan bahwa:

1. Mahasiswa yang berkemampuan matematika rendah hanya mampu menyelesaikan 1 tema soal model PISA level 4 konten bilangan, serta memperoleh nilai 31 dan 35

2. Mahasiswa yang berkemampuan matematika sedang hanya mampu menyelesaikan 2 tema soal model PISA level 4 konten bilangan, serta memperoleh nilai 77 dan 76

3. Mahasiswa yang berkemampuan matematika tinggi mampu menyelesaikan 3 tema soal model PISA level 4 konten bilangan, serta memperoleh nilai 88 dan 92

Dari ketiga kesimpulan diatas, maka dapat dikatakan bahwa mahasiswa yang berkemampuan matematika rendah belum mampu menyelesaikan soal model PISA level 4 konten bilangan, sedangkan mahasiswa berkemampuan matematika sedang dan tinggi sudah mampu menyelesaikan soal model PISA level 4 konten bilangan. .

\section{Saran}

Berdasarkan kesimpulan yang diperoleh, maka peneliti memberikan saran kepada mahasiswa dan peneliti selanjutnya, sebagai berikut.

1. Mahasiswa dapat mempelajari soal matematika bertipe model PISA level 4 konten bilangan lebih mendalam agar bisa menjadi bahan ajar untuk siswa jika sudah menjadi guru.

2. Bagi peneliti diharapkan untuk melakukan penelitian sejenis,untuk mengetahui perkembangan kemampuan matematis mahasiswa dalam menyelesaikan soal model PISA konten bilangan. 


\section{Daftar Pustaka}

Anisah, Zulkardi, \& Darmawijoyo. (2013). Pengembangan Soal Matematika Model PISA Pada Konten Quantity Untuk Mengukur Kemampuan Penalaran Matematis Siswa Sekolah Menengah Pertama. Jurnal Pendidikan Matematika, V(1) : 1-14

Disnawati, H. (2018). Literasi Matematika: Kemampuan Mahasiswa Calon Guru Di Wilayah Perbatasan Indonesia-Timor Leste. Prosiding KNPMP III,2018, (pp. 773779). Surakarta: UMS Surakarta.

Putri, R.S. (2015). "Analisis Keterampilan Metakognitif Siswa dalam Menyelesaikan Masalah Matematika Berbasis Polya Subpokok Bahasan Garis dan Sudut Kelas VII-C di SMP Negeri 1 Gentang Banyuwangi”. Skripsi. Universitas Jember.

Setiawan, H., dkk. (2014). Soal Matematika Dalam PISA Kaitannya Dengan Literasi Matematika Dan Keterampilan Berpikit Tingkat Tinggi. Prosiding Seminar Nasional Matematika, 2014, (pp.244-251).Universitas Jember.

Stacey, K. (2011).The View of mathematics Literacy in Indonesia: Journal on mathematics Education( Indo-MS_JME).2(2), (pp.95-126).Palembang: JME

Sulastri, R., dkk. (2014). Kemampuan Mahasiswa Program Studi Pendidikan Matematika FKIP Unsyiah Menyelesaikan Soal PISA Most Difficult Level Most Difficult.Jurnal Didaktif Matematika. Vol. 1(2) : 13-20.

Tohir, M. (2019). Hasil PISA Indonesia tahun 2018 turun dibanding tahun 2015: Artikel,(online):https://matematohir.wordpress.com/2019/12/03/hasil-PISAindonesia-tahun-2018-turun-dibanding-tahun-2015/ diakses 22 Maret 2021

Zulkardi, dkk. (2016). Pengembangan soal matematika model PISA Model Konten Bilangan untuk mengetahui kemampuan Literasi matematika Siswa . Jurnal Pendidikan Matematika. 2(1), (pp.14-26). Palembang:JPM. 